Meta

Journal des traducteurs

Translators' Journal

\title{
Charles Baudelaire and his Translation Edgar Allan Poe
}

\section{Pamela Faber}

Volume 34, numéro 2, juin 1989

URI : https://id.erudit.org/iderudit/002735ar

DOI : https://doi.org/10.7202/002735ar

Aller au sommaire du numéro

Éditeur(s)

Les Presses de l'Université de Montréal

ISSN

0026-0452 (imprimé)

1492-1421 (numérique)

Découvrir la revue

Citer cet article

Faber, P. (1989). Charles Baudelaire and his Translation Edgar Allan Poe. Meta, 34(2), 253-259. https://doi.org/10.7202/002735ar d'utilisation que vous pouvez consulter en ligne.

https://apropos.erudit.org/fr/usagers/politique-dutilisation/ 


\section{CHARLES BAUDELAIRE AND HIS TRANSLATIONS OF EDGAR ALLAN POE}

PAMEla FABER

Translator, Granada, Spain

One of the most interesting chapters of translation history is the translation of the works of Edgar Allan Poe by Charles Baudelaire. Baudelaire's translations of Poe comprise five of the twelve volumes of his collected works and have themselves become classics in the target language.

Poe's French image has been in many ways determined by Baudelaire. The 47 texts he translated are far from being the entirety of Poe's works. There were 30 essays and short stories which did not appear until 90 years later in Lemonnier's version (Classiques Garnier, 1950).

The fact that Poe's French face is considerably more attractive than his English one leads us to ask ourselves in what measure Baudelaire's translations might be responsible for this difference in critical opinion. Roger Asselineau (1967: 99) comments that most of Poe's enthusiasts are French while his detractors are invariably Anglo-Saxon and attributes this to Baudelaire.

Baudelaire's encounter with Poe's work transformed his own talent and changed his destiny, Valéry (1930: 129-166) writes of an exchange of values. In his aesthetic theory, Poe gave a new system of thought to Baudelaire, while Baudelaire's gift to Poe was that of immortality. Baudelaire's poetry (not Poe's) is the best argument for Poe's aesthetic doctrine. Valéry describes this as translation, but in this case, the SL is literary doctrine and the TL is the poetry which it embodies.

Baudelaire began to translate Poe because of his admiration for Poe's work and because of its resemblance to his own. He is proof that spiritual affinity or belief in the author one is translating can be just as important or, in this case, more so than a perfect knowledge of the languages in question. For Baudelaire's knowledge of English was far from perfect. T. S. Eliot goes so far as to state that "there is no reason to believe that he spoke the language at all" (Eliot 1965: 36). A note given to Eugene Crepet by Ernest Prarond tells us, however, that Baudelaire's mother, who had been born in England and spent her childhood there, spoke English as well as French to him from the cradle (Crepet 1933: 353).

Baudelaire first translated various of Poe's tales for newspapers such as the Revue de Paris, l'lllustration, le Pays, le Figaro, and le Monde illustré among others. They were later published in the following collections: Histoires extraordinaires (1856), Nouvelles histoires extraordinaires (1857), les Aventures de Arthur Gordon Pym (1857), and Histoires grotesques et sérieuses (1865).

His translations were an immediate success. Some of the critics expressed their reservations towards Poe, but the reviews were unanimous in praising his translator.

A. Legendre acclaims Baudelaire as a fine and conscientious artist (le Figaro: April 10, 1856). 
Émile Deschanel compliments Baudelaire on his style and goes so far as to say that his translations are as remarkable as the original text (Indépendance belge: August 19, 1857).

Edmond Duranty even writes that Baudelaire's translations had rescued his declining literary reputation (le Figaro: November 13, 1856).

Perhaps the most striking characteristic of his translations is their scrupulous adherence to the original text. Even the earliest versions, which were written from day to day to meet newspaper deadlines, are extraordinarily faithful, though Baudelaire in this first stage at times chooses meaning over form.

In his introduction to la Révélation magnétique (1848), he excuses his "français pénible et parfois baroque," but justifies himself saying that it is the best way to translate the total content of the original text, which the translator must render faithfully at all costs (la Liberté de penser: July 15,1848 ).

He often overlooked idiomatic convention to preserve the flavour and rhythm of the original. Certain literary critics of his time, such as Émile Deschanel (l'Indépendance belge: Feb. 12, 1857), criticized what they labeled his excessive use of neologisms.

Philippe Dauriac (le Monde illustré: April 8, 1865) compliments Baudelaire's use of language, but comments on its deviation from the accepted concept of French literary style.

T. S. Eliot maintains that Baudelaire transformed what was often "a slipshod and shoddy English prose into admirable French" (Eliot 1965: 36).

David Galloway, however, disagrees with Eliot. He writes:

T. S. Eliot's suggestion that Poe's profound influence on the French resulted from improvement in the translation is of little worth. Baudelaire's translations of the tales [...] are remarkable for their authenticity and adherence, wherever idiom permits to Poe's phraseology (Galloway 1967: 12).

I would like to suggest the possibility that both of their assertions are correct. Baudelaire did transform Poe's prose into admirable French, but he achieved this transformation by faithfully translating form and meaning. The fact that Poe reads better in French than in English is due to the nature of his subject matter, to certain linguistic quirks in his style, to the grammatical and sound systems of the two languages in question, and to Baudelaire's devotion and talent. This is more evident if we examine Poe's work and its French translation within the context of the four main sources of entropy proposed by Newmark (1981: 7-8).

Entropy Source 1: when "the text describes a situation which has elements peculiar to the natural environment, institutions, and culture of the language area":

Poe's tales translate well precisely because they have nothing to do with his immediate surroundings. Some critics, such as J. W. Krutch (1926) go so far as to say that he has no place in the American literary tradition. If one attempts to situate Poe geographically, he does seem more like a displaced European. Baudelaire certainly felt that America was Poe's prison and mistakenly believed that in his youth, he had gone to Greece to fight the Turks (in the best Byronic tradition) and had later traveled extensively in Russia.

This, however, was a convenient fiction Poe had invented to explain away the years he had spent as an enlisted man in the army. There is no reason to believe that he ever had any other contact with Europe other than the five years he spent in England as a small boy. 
However, one searches in vain, for pictures and scenes of 19th century America in his writing. There are none. The explanation for this can be found in Poe's own definition of art as "the reproduction of what the Senses perceive in Nature through the veil of the soul" and in his absolute rejection of the principle of imitation in "Art."

The unrelenting intensity of his pictures is created from essentially Gothic materials such as decaying mansions, the ruins of ancient abbeys, shadowy faraway lands peopled by twilight zone heroes and heroines. This is a country fabricated by Poe and its evident lack of reality is exactly what he sought. The interplay of elements within the text aimed at achieving a desired effect is his paramount concern and not their possible correspondence to some aspect of the real world. Todorov comments on this disproportion between paradigmatic and syntagmatic reference in Poe's writing:

Mais rarement la disproportion des facteurs atteindra un degré aussi élevé que chez Poe. Ici, rien n'est imitation, tout est construction et jeu. (Todorov $1974: 14$ ).

The consequences of this are obvious when we consider the translation process. The lack of cultural references in Poe's writing facilitates its transferral to other languages and minimizes the possible loss of information. Thus when translating Poe, Baudelaire only had to be concerned with the elements within the text, their interaction and form, but not to any possible reference to reality.

Entropy Source 2: "the fact that the two languages, both in their basic character (langue) and their social varieties (parole) in context have different lexical, grammatical and sound systems and segment many physical objects and virtually all intellectual objects differently."

There is always a certain loss of meaning in translation due to the structural differences of the languages in question. I believe, however, that there are writers whose style lends itself more to translation than others and that Poe is one of these writers.

To an Anglo-Saxon reader accustomed to short sentences and a certain sobriety of style, Poe's writing often seems overdone. His myriad use of adjectives and postnominal phrases, the length and complexity of his sentences, the frequent insertion of Latin, Greek, and French words make his literary style as affected as that of an 18th century English essayist. But these stylistic quirks which so irritate Anglo-Saxon readers are precisely what minimizes the inevitable entropy in its translation process.

The standards of stylistic acceptability for various types of discourse differ radically from language to language (Nida 1964). Literary artists of romance languages take delight in the same flowery elegance of language that many English writers (not Poe, of course) have rejected in favor of realism, precision, and movement. Thus, those of Poe's texts which in English read like "purple prose" (to use Nida's expression) become entirely appropriate in French or Spanish. We have only to read him in Baudelaire's or Cortàzar's version to see the difference.

Much of the artificiality and false elegance of Poe's style lies in his use of adjectives. He never uses one where he can put three. Many of these interminable strings of modification are in postnominal position. For example, in The Fall of the House of Usher alone, there are 19 cases of this kind of stylistic deviation: (i.e. "an eye large, liquid, and luminous," "a pestilent and mystic vapour, dull, sluggish, faintly discernible, and leadenhued," etc.)

Epstein (1980) underlines the importance of the position of adjectives. According to him, adjectives should be considered as signs within the value system of the writer and as such, produce different effects according to their position within the text. Poe's consis- 
tent use of postnominal modification, which in English constitutes a stylistic deviation, is done to achieve a heightened poetic effect. Unfortunately, the very frequence of this recourse cancels out the intended effect and only succeeds in making Poe's prose dated and often tiresome.

However, when Poe is translated to French, the structure of the target language acts as a filter which eliminates much of what English readers criticize in his writing. In French, the postnominal position of Poe's adjectives ceases to be a stylistic deviation. "An eye, large, liquid, and luminous" becomes "un ceil large, liquide et lumineux." Due to the greater degree of mobility that French adjectives enjoy (and the other elements of the sentence as well), the form of the original is translated, but not its overdone poeticity. The fortunate result of the translation, in this case, is due more to the structure of the target language than to the genius of the translator.

Exactly the same thing occurs with Poe's archaisms. There is hardly a page of his writing that doesn't contain the affected use of archaic language, in terms of vocabulary and word order, to achieve a conscious stylistic effect of poeticity, as in the following passage of Morella:

The days have never been when thou couldst love me but her whom in life thou didst abhor, in death thou shalt adore... Morella! how knowest thou this?

However, none of this is evident in the translation:

Ils n'ont jamais été, ces jours où il t'aurait été permis de m'aimer ;- mais celle que, dans la vie, tu abhorras, dans la mort du l'adoreras... Morella! comment sais-tu cela?

This is due mainly to the lack of equivalent in French for the English biblical pronouns and verb forms and the difference in word order of the two languages in question. Once again, the translation reads better than the original text because of the structure of the target language which filters out the worst of Poe's stylistic recourses.

The same thing occurs as well on the sound level. The French translation spares us many of Poe's alliterations. This loss of information can be called fortunate since Poe often employed words more for their sound than for their sense, as in the following extract from Ligeia:

... the character of my beloved, her rare learning, her singular yet placid cast of beauty, and the thrilling and enthralling eloquence of her low musical language, made their way into my heart by paces so steadily and stealthily progressive that they have been unnoticed and unknown.

In this case, the different sound systems of the two languages constitutes a blessing. The French translation only conserves the alliteration in the first pair of adjectives : "thrilling and enthralling"/ "pénétrante et subjugante."

Thus the "music" of Poe's prose is not translated or, as D. H. Lawrence called it, "the mechanical quality of Poe's style" (Lawrence 1947: 676). What remains the same is the combination of elements and themes within the narration which is, I believe, where Poe's claim to genius lies.

Entropy Source 3: "The individual uses of language of the text-writer and the translator do not coincide."

Entropy Source 4: "Lastly the translator and the text-writer have different theories of meaning and different values." 
The last two sources of entropy can be examined together since they are based on the degree of literary and linguistic empathy existing between author and translator.

In this respect, the relation between Poe and Baudelaire could not have been more ideal. Baudelaire's personal papers are full of statements expressing the affinity of Poe's ideas, literary style, and writing with his own. In a letter to his mother (March 8, 1854 in Crepet 1933a: 352), Baudelaire remarks on the subtle resemblance of his poetry to Edgar Allan Poe's.

Baudelaire's resemblance to Poe was evident to others as well. In 1857, Charles Monselet compliments the excellence of Baudelaire's translations and suggests that it is due to the many things both authors have in common (la Lorgnette literaire: 1857).

Baudelaire saw himself as Poe, an exotic trapped and finally destroyed by a hostile and intolerant world, "a great, barbarous realm equipped with gas fixtures," which could not appreciate the rare light of his genius. He admits that in Poe's work, he found his own. We can thus surmise that the individual uses of language of the text-writer (Poe) and the translator (Baudelaire) coincided to a startling degree.

As for their theories of meaning and values, we have only to remember that Baudelaire adopted Poe's aesthetic theory as his own, recited whole passages of his work by heart, and preached his worth to all who would listen.

Poe's influence in Baudelaire's work is manifest. Mon cour mis à $n u$ was inspired by Poe's Marginalia. In his Journaux intimes (in 1980: 404), he goes so far as to pray to Poe to intercede for him so that his prayers will be answered.

Baudelaire's great admiration for Poe and the fervent belief in his writing and ideas was part of the success of his translations. Because of him, the French Symbolists made Poe into a sacred book. R. P. Blackmur $(1960: 380)$ even states that Baudelaire made Poe a great writer by giving his writing in French the authority, the genuineness to which it never pretended in English. His translation transfigures, but this is only possible when the translator's sensibility is so in tune to the text-writer's that he virtually becomes the text-writer in the target language. Baudelaire managed to do this, thus eliminating the fourth source of entropy.

\section{CONCLUSION}

In my opinion, a particular set of qualities and circumstances combined to produce this "permanent and public translation" (Blackmur 1960: 380) that has made Poe an important author in the French language: (1) The translatability of Poe's style; (2) The lack of paradigmatic references in his writing; (3) The structure of the target language which filters out the worst of Poe; (4) The chronological proximity of the text-writer and translator; (5) The identification of the translator with the text-writer on all levels.

However, if we maintain that the main aim of the translator is to produce as nearly as possible the same effect in his readers as was produced in the readers of the original text (Rieu 1953), Baudelaire's translation is by no means perfect. He did not faithfully reproduce Poe's style. French readers have come to know Poe in a purified and refined version. 


\section{BIBLIOGRAPHY}

\section{Collections :}

Baudelaire : petits poèmes en prose, ceuvres critiques (1971): Paris, Nouveau classiques Larousse.

Baudelaire : CEuvres complètes (1980) : Paris, Robert Laffont.

Edgar Allan Poe (1977) : Philip Van Doren Stern (Ed.), New York, Viking Press.

Histoires extraordinaires (1933a) : Critical edition by Jacques Crepet, Paris, Louis Conard.

Nouvelles histoires extraordinaires (1933b) : Critical edition by Jacques Crepet, Paris, Louis Conard.

Histoires grotesques et sérieuses (1933c) : Critical edition by Jacques Crepet, Paris, Louis Conard.

Edgar Poe : Tales / Contes (1968) : introduction by Roger Asselineau, Paris, Bilingue Aubier Flammarion.

\section{Newspapers :}

Indépendance belge (Feb. 12, Aug. 19, 1857), Brussels.

La Liberté de penser (July 15, 1848), Paris.

La Lorgnette literaire (1857), Paris.

Le Figaro (April 10, Nov. 13, 1856), Paris.

Le Monde illustré (April 8, 1865), Paris.

Mercure de France (Sept. 16, 1912), Paris.

\section{Other References :}

BLACKMUR, R. P. (1960): Afterword in Edgar Allan Poe : The Fall of the House of Usher and Other Tales, New York, Signet.

ELIOT, T. S. (1948) : "From Poe to Valery," in To Criticize the Critic (1978), London, Faber \& Faber.

EPSTEIN, E. L. (1980): "Non-Restrictive Modifiers: Poetic Features of Language" in Greenbaum et al. (1980): Studies in English Linguistics for Randolph Quirk, London, Longman.

GALLOWAY, D. (1967): Introduction in Edgar Allan Poe: Selected Writings, Harmondsworth, Middlesex, Penguin.

KRUTCH, J. W. (1926) : Edgar Allan Poe : A Study in Genius, New York, Alfred A. Knopf.

LAWRENCE, D. H. (1923): "Edgar Allan Poe" in The Portable D. H. Lawrence (1977), Diana Trilling (ed.), Harmondsworth, Middlesex, Penguin.

NEWMARK, P. (1981) : Approaches to Translation, Oxford, Pergamon Press.

NIDA, E. A. (1964): Toward a Science of Translating, Leiden, Brill.

RIEU, E. V. (1953) : "Translation" in Cassell's Encyclopedia of Literature, vol. 1, London, Cassell.

TODOROV, T. (1974) : Preface of Nouvelles histoires extraordinaires, Paris, Gallimard.

VALERY, P. (1930) : Variétés II, Paris; Gallimard. 